\title{
PENGINDERAAN JAUH UNTUK KAJIAN PESISIR
}

\author{
Oleh \\ Nurul Ihsan Fawzi ${ }^{1)}$ dan Marindah Yulia Iswari ${ }^{2)}$
}

\begin{abstract}
REMOTE SENSING FOR COASTAL STUDIES. Coastal ecosystem is an ecological system that is important and the most productive area on earth. On the other hand, pressure on coastal ecosystems for human necessity cause decrease quality of coastal ecosystems. Utilization of coastal areas requires the proper management and suitable with objective. Good management requires appropriate information for decisionmaking. For spatial data, acquisition of information through remote sensing data is the best option. This paper will discuss the utilization of using remote sensing for coastal analysis. Coastal management requires information accurately and quickly to follow up issues or problems that growth up. Remote sensing has provided the capability to provide that information by translating information from digital number to thematic information. Regardless from the problem existing mapping method, utilization remote sensing in the future will be the main data on coastal management, especially in the monitoring and measurement of biophysical parameter in coastal areas.
\end{abstract}

\section{PENDAHULUAN}

Ekosistem pesisir adalah sistem ekologis yang sangat penting dan area paling produktif di muka bumi (Brown \& Hausner, 2017). Hampir seluruh aktivitas di muka bumi berada di kawasan pesisir, yang ditandai dengan adanya sebagian kota-kota besar dunia di kawasan tersebut (Glavovic, 2013). Hal ini mengingat bahwa pesisir merupakan zona perbatasan antara darat dan laut yang memiliki peran sangat penting dalam pembangunan. Pada sisi lain banyak terjadi tekanan penggunaan ekosistem pesisir untuk kebutuhan manusia, yang dampaknya memicu menurunnya kualitas ekosistem pesisir (Lotze et al., 2006), seperti meningkatnya populasi manusia di kawasan ini. Dampak tersebut meningkatkan polusi pada kawasan pesisir (Vikas \& Dwarakish, 2015), kerusakan ekosistem alami, erosi pesisir (Van Rijn, 2011), meningkatnya kerentanan pesisir terhadap bencana (Adger et al., 2005; De Sherbinin et al., 2007), dampak kenaikan muka air laut yang semakin besar (Williams, 2013), hingga pencemaran tumpahan minyak mentah (Beyer et al., 2016).

Pemanfaatan kawasan pesisir membutuhkan pengelolaan yang tepat dan sesuai dengan sasaran berdasarkan informasi yang baik dan tepat untuk pengambilan keputusan (Malone et al., 2010). Penyediaan informasi tersebut dapat bersifat spasial dan tidak. Untuk data-data spasial, perolehan informasi melalui data penginderaan jauh adalah

\footnotetext{
1) Program Konservasi, Yayasan Alam Sehat Lestari, Kalimantan Barat

${ }^{2)}$ Pusat Penelitian Oseanografi, LIPI
} 
yang terbaik untuk saat ini. Tujuan dari review ini adalah untuk memberikan gambaran komprehensif bagaimana teknik penginderaan jauh mampu menyelesaikan isu-isu pada kawasan pesisir. Data-data spasial yang ada dapat diintegrasikan dengan data-data lainnya seperti sosial ekonomi, ekosistem dan vegetasi, untuk menghasilkan perencanaan dan tindakan yang tepat sasaran. Apalagi untuk data-data yang bersifat multitemporal, penginderaan jauh dengan pengembangan lebih dari 40 tahun mampu menyediakan analisis untuk monitoring kawasan pesisir.

\section{ISU-ISU PADA KAWASAN PESISIR}

Dalam kajian mengenai pesisir dan kepesisiran, hal utama yang dilakukan adalah inventarisasi sumberdaya. Sumberdaya tersebut baik berupa sumberdaya alam yang terdapat pada ekosistem pesisir, maupun sumberdaya manusia seperti faktor sosial-ekonomi. Inventarisasi berguna sebagai informasi atas permasalahan dan isu-isu pesisir yang membutuhkan penyelesaian. Atas dasar itu, monitoring kawasan pesisir dapat terstruktur dan memberikan input yang sesuai. Berikut adalah isu-isu di kawasan pesisir yang membutuhkan perolehan informasi.

\section{Informasi Sumberdaya Pesisir dan Kelautan.}

Informasi tentang sumberdaya pesisir dan kelautan merupakan hal terpenting untuk dapat digunakan dalam suatu perencanaan maupun pengelolaan pesisir yang tepat. Sumberdaya pesisir tersebut dapat berupa penggunaan lahan, zonasi ruang, habitat spesies, ekosistem alami pesisir, perubahan kawasan pesisir, kondisi biofisik seperti pasang surut, kandungan klorofil, dan kerapatan vegetasi, hingga pencemaran yang terjadi. Hal yang paling utama adalah perbaikan data referensi informasi sumberdaya tersebut agar layak digunakan. Data-data tersebut dapat menjadi dasar pengelolaan yang sesuai untuk konservasi ekosistem pesisir, reklamasi pantai untuk tujuan industri ataupun pembangunan, ekplorasi pesisir dan penggunaan sumberdaya yang berkelanjutan.

\section{Perlindungan Garis Pantai.}

Dinamika pesisir yang terjadi adalah terjadinya erosi dan akresi (Van Rijn, 2011). Erosi dapat diartikan dengan berkurangnya daratan pantai secara perlahan akibat aktivitas gelombang laut. Hal tersebut mengakibatkan perubahan garis pantai sebagai dampak berkurangnya daratan atau terbentuknya delta akibat sedimentasi. Upaya inventarisasi dan perlindungan terhadap garis pantai menjadi penting untuk mencegah kehilangan garis pantai yang lebih besar. Secara lebih luas adalah perencanaan dan implementasi perlindungan garis pantai pesisir terhadap erosi, banjir, intrusi air laut, dan dampak yang ditimbulkan. Isu perubahan iklim menjadi hal utama yang harus diperhatikan, karena memberikan dampak langsung terhadap perubahan garis pantai (Zhang et al., 2004) seperti monitoring dinamika material tersuspensi pada kawasan pesisir dan monitoring perubahan topografi dasar laut pada kawasan pesisir yang dilalui lalu lintas laut (Zaggia et al., 2017). 


\section{Kualitas Air di Pesisir}

Meningkatnya populasi manusia dan aktivitas pembangunan pada kawasan pesisir memicu meningkatnya pencemaran yang terjadi (Corcoran et al., 2010; Gandy, 2004), apalagi pada kotakota di negara berkembang yang belum baik sistem drainasenya. Kualitas air tersebut dapat diukur melalui kandungan material tersuspensi (Lasut et al., 2016), intrusi air laut (Werner \& Simmons, 2009), ledakan fitoplankton (Teeling et al., 2012; Yuliana et al., 2012), tumpahan minyak (Sulistyono et al., 2012), dan bentuk pencemaran lainnya.

\section{Bencana pada Pesisir dan Adaptasi Perubahan Iklim.}

Bencana tsunami di Aceh pada tahun 2004 telah merusak kawasan pesisir dengan intensitas yang cukup parah (Doocy et al., 2007; National Geographic Indonesia, 2014). Ekosistem alami di kawasan pesisir yang berupa hutan mangrove, ekosistem dasar laut dan perkotaan telah hancur oleh tsunami tersebut (Monecke et al., 2008). Pada negara-negara subtropis, selain tsunami dapat terjadi pula badai dan tornado yang dapat merusak kawasan pesisir (Emanuel, 2005). Bencana yang perlahan muncul adalah dampak dari kenaikan muka air laut yang perlahan menenggelamkan area di pesisir (Sofian et al., 2011). Dalam hal ini respon darurat diperlukan untuk mitigasi maupun penyusunan rencana kontijensi jika terjadi bencana (Singkran, 2014).

\section{Pembangunan di Kawasan Pesisir.}

Isu tantangan reklamasi pantai utara Jakarta dan reklamasi Teluk Benoa, Bali telah banyak menimbulkan protes, karena dianggap merusak ekosistem alami pesisir (Sampono et al., 2012). Permasalahan pembangunan di kawasan pesisir haruslah ditangani berdasarkan studi yang lebih lanjut dan diatur dalam zonasi kawasan yang komprehensif, sehingga dalam pemilihan lokasi yang tepat untuk industri, tambak, hingga aktivitas rekreasi dapat dilakukan dengan baik.

\section{PEROLEHAN INFORMASI \\ PESISIR MENGGUNAKAN \\ PENGINDERAAN JAUH}

\section{Apa Itu Penginderaan Jauh?}

Penginderaan jauh merupakan teknik untuk mendapatkan informasi mengenai objek di permukaan bumi tanpa kontak fisik dengan objek tersebut. Teknik ini menggunakan perekaman gelombang elekromagnetik atas area di permukaan bumi yang direpresentasikan dalam sebuah citra atau gambar. Berbagai citra yang dihasilkan ini selanjutnya diproses untuk beragam aplikasi di bidang pertanian, kebumian, aplikasi spesifik untuk ekologi dan bidangbidang lainnya (Fawzi, 2016a). Lo (1987) menjelaskan, bahwa tujuan utama penginderaan jauh adalah mengumpulkan data sumberdaya alam dan lingkungan. Informasi tersebut disampaikan melalui gelombang elektromagnetik. Inti dari penginderaan jauh adalah interpretasi permukaan bumi dari sebuah citra atau 
perekaman fotografik (Fawzi, 2016b). Untuk mendapatkan hasil interpretasi yang mendekati kenyataan, maka perlu mengetahui karakteristik sistem penginderaan jauh itu sendiri. Dengan demikian, dapat dikatakan bahwa data penginderaan jauh pada dasarnya merupakan informasi intensitas panjang gelombang yang perlu diterjemahkan dalam bentuk informasi tematik.

\section{Mengapa Menggunakan Penginderaan Jauh}

Kebutuhan informasi yang tepat adalah hal yang mutlak dalam suatu pengambilan keputusan maupun dalam suatu program pengelolaan (Fawzi \& Jatmiko, 2018). Penggunaan penginderaan jauh memiliki kelebihan yang tidak dapat diperoleh dengan metode lain, seperti kemampuan dalam observasi, analisis dan pengukuran, monitoring baik temporal maupun spasial, serta mendukung pengambilan keputusan. Adapun beberapa kelebihan dari penginderaan jauh adalah sebagai berikut.

\section{a. Observasi}

Observasi adalah deteksi dan identifikasi terhadap kondisi habitat atau suatu wilayah. Dengan beragam satelit penginderaan jauh, dapat dilakukan observasi untuk mendeteksi keberadaan titik panas akibat kebakaran hutan yang terjadi. Dengan kemampuan synoptic view (memberi gambaran secara ringkas dan menyeluruh atas suatu wilayah), repetitif, dan multispektral telah terbukti memberikan informasi observasi pesisir.
Dengan observasi bumi menggunakan data penginderaan jauh, dimungkinkan untuk mendapatkan informasi mengenai perubahan lingkungan dan monitoringnya dalam skala yang berbeda (De Araujo Barbosa et al., 2015). Hasil observasi ini dapat berupa data geospasial untuk pasang surut air laut, lokasi potensial akuakultur, ekosistem mangrove dan estuari, perubahan sedimen, batimetri, maupun ekosistem bawah laut pesisir.

\section{b. Pengukuran dan Analisisnya}

Salah satu $r$ kemampuan
penginderaan jauh yang banyak
digunakan adalah $r$ mampu
mengkuantifikasi fenomena-fenomena
di permukaan bumi dengan beragam
pendekatan. Variabel fisik dan biologi
dapat diukur dengan penginderaan jauh,
misalnya ketinggian, produktivitas, tipe
awan, suhu permukaan, jumlah curah
hujan, kecepatan angin, dan kualitas air.
Beragam algoritma dikembangkan untuk
beragam aplikasi tersebut.

\section{c. Pemetaan}

Pemetaan berhubungan dengan data spasial, karena output akhir dari pengolahan data spasial adalah peta. Salah satu peta yang dihasilkan dari penginderaan jauh yang paling umum adalah peta klasifikasi penggunaan lahan. Hasil-hasil observasi, pengukuran dan analisisnya, pada akhirnya akan divisualisasikan dalam bentuk peta untuk mempermudah pemahaman mengenai persebaran dan polanya. Selain itu, fitur fisik lahan juga dapat dibuat petanya, seperti tipe pesisir, vegetasi, habitat, awan, atau distribusi terumbu karang. 


\section{d. Monitoring}

Penginderaan jauh telah mulai digunakan sejak tahun 1960an (Melesse et al., 2007). Data sejak saat itu dapat digunakan untuk dibandingkan dengan data saat ini untuk melihat perubahan permukaan bumi yang terjadi. Dengan kemampuan inilah, maka penginderaan jauh dapat menjadi alat utama dalam monitoring fenomena yang terjadi di permukaan bumi. Monitoring perubahan penggunaan lahan, kebakaran hutan, pola fragmentasi, hingga monitoring cuaca dan iklim (Klemas, 2011). Semuanya dapat dilakukan berkat ketersediaan data perekaman dari waktu ke waktu. Dengan demikian, usaha-usaha konservasi berawal dari hal ini (Fawzi, 2017). Hal ini tentunya dapat digunakan untuk memprediksi kejadian yang akan datang dan menentukan strategi pengelolaannya.

\section{e. Pengambilan Keputusan/Manajemen}

Ini adalah alasan paling utama dari penggunaan penginderaan jauh, sebagai bahan masukan dan proses dari pengambilan keputusan terutama dalam pengelolaan pesisir, termasuk pengambilan keputusan untuk pengelolaan kawasan lindung dan pemetaan perubahannya. Dapat dikatakan, pada keputusan yang menyangkut fenomena di permukaan bumi, keberadaan data penginderaan jauh untuk pengambilan keputusan mutlak sangat dibutuhkan.

\section{f. Data-Data Penginderaan Jauh}

Data penginderaan jauh merupakan data hasil perekaman permukaan bumi oleh sensor penginderaan jauh. Sensor penginderaan jauh merekam intensitas gelombang elektromagnetik yang mencapai sensor dengan unit radiasi yang diterima sensor $\mathrm{W} /\left(\mathrm{m}^{2} . \mathrm{sr} . \mu \mathrm{m}\right)$. Nilai yang terekam tersebut dengan satuan $\mathrm{W} /\left(\mathrm{m}^{2}\right.$.sr. $\left.\mu \mathrm{m}\right)$ pada tiap-tiap band dikonversi menjadi nilai piksel (digital number) pada citra yang proposional dengan resolusi radiometrik sensor tersebut. Sebagai contoh misalnya Landsat TM dengan rentang nilai piksel 0 - 55, berbeda dengan Landsat generasi sebelumnya (MSS) yang hanya 0-63, dan sensor terbaru memiliki resolusi radiometrik yang semakin baik, hingga 12 bit, artinya mampu membedakan unit radiasi semakin detail.

Jenis data dalam penginderaan jauh dibedakan atas metode akuisisi, atau metode perekamannya. Data dalam penginderaan jauh sendiri terdiri atas data penginderaan jauh pasif dan aktif. Perbedaan keduanya adalah panjang gelombang yang digunakan dan metode akuisisi datanya. Akan tetapi, dalam penjelasan yang lebih praktis, data penginderaan jauh adalah permukaan bumi yang direpresentasikan dalam bentuk citra dengan nilai-nilai piksel yang perlu dikoreksi dan diterjemahkan kedalam informasi tematik. Secara lebih detail tentang alur interpretasi penginderaan jauh, disajikan pada gambar (1). 


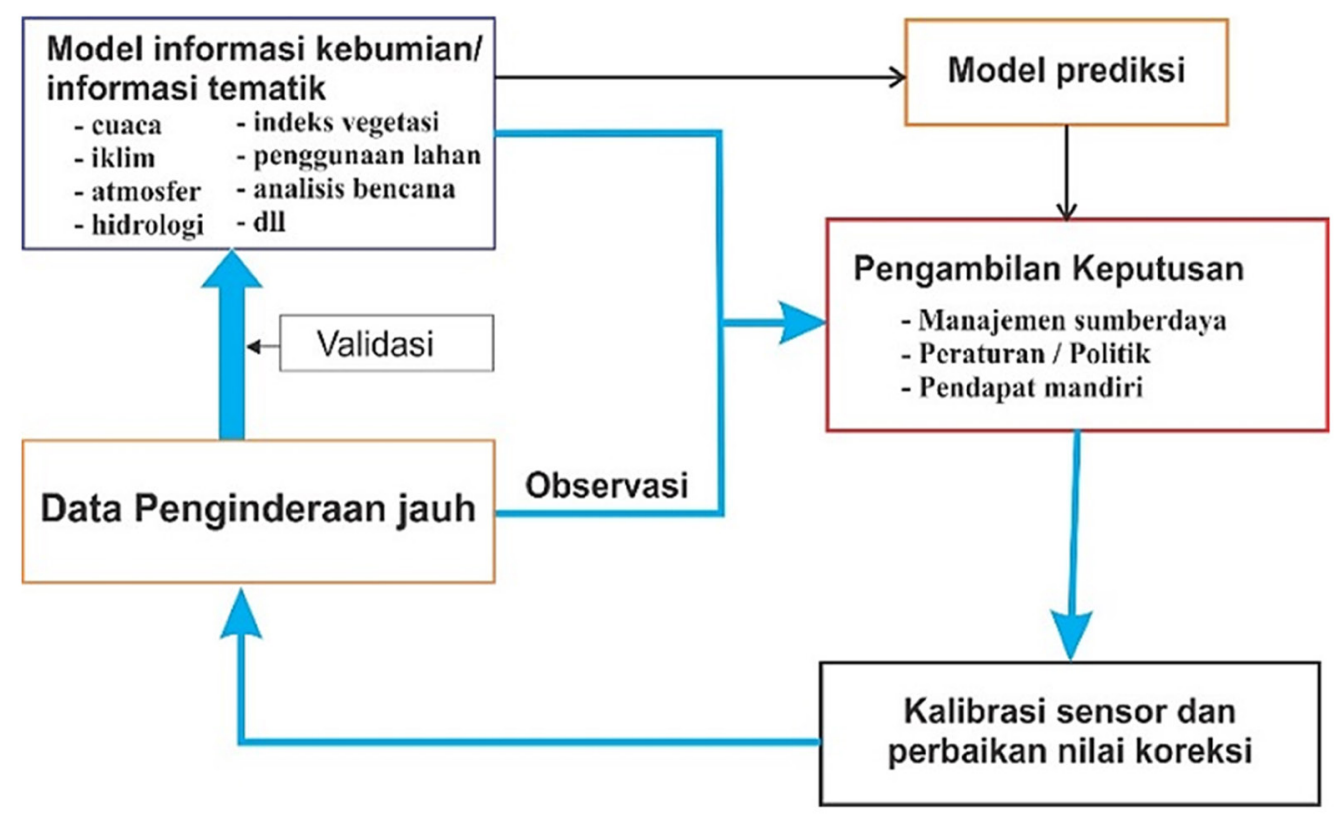

Gambar 1. Komponen dalam penginderaan jauh, merupakan suatu siklus analisis untuk menghasilkan pemetaan yang lebih baik (Fawzi \& Jatmiko, 2018)

\section{Bagaimana Data Tersebut Didapatkan?}

Data penginderaan jauh saat ini telah banyak tersedia, baik dapat diunduh secara gratis ataupun berbayar. Untuk saat ini, terdapat 29 satelit penginderaan jauh yang mengorbit yang dapat diperoleh datanya dan 34 satelit akan diluncurkan (Kuenzer et al., 2013). Citra dengan resolusi menengah seringkali telah dapat diunduh secara gratis sedangkan citra dengan resolusi tinggi, hampir seluruhnya harus dipesan dan berbayar. Jika ingin mendapatkan secara gratis untuk penelitian, ada baiknya untuk menghubungi LAPAN dan mengikuti prosedur untuk mendapatkannya. Akan tetapi, hal ini berbeda halnya dengan perolehan citra melalui foto udara, harus melalui banyak persiapan dan biaya yang tidak sedikit. Beberapa direktori untuk memperoleh data penginderaan jauh disajikan pada Tabel (1).

Tabel 1. Penyedia produk penginderaan jauh dan direktori unduhan.

\begin{tabular}{|c|l|}
\hline Nama Penyedia & \multicolumn{1}{|c|}{ Keterangan } \\
\hline USGS Earth Explorer & $\begin{array}{l}\text { Earth Explorer menyediakan pencarian online untuk data } \\
\text { penginderaan jauh pada arsip USGS, yang memungkinkan } \\
\text { untuk mengunduh citra penginderaan jauh, foto udara, data } \\
\text { ketinggian, produk tutupan lahan, dan peta digital. } \\
\text { url: http://earthexplorer.usgs.gov/ }\end{array}$ \\
\hline
\end{tabular}




\begin{tabular}{|c|c|}
\hline $\begin{array}{l}\text { USGS Global } \\
\text { Visualization Viewer } \\
\text { (GloVis) }\end{array}$ & $\begin{array}{l}\text { Glovis adalah situs pencari yang sama dimiliki oleh USGS } \\
\text { dengan tampilan yang lebih sederhana. Untuk mengunduh citra } \\
\text { pada glovis, kita perlu membuat akun terlebih dahulu (yang } \\
\text { dapat digunakan juga di Earth Explorer). Citra yang tersedia di } \\
\text { glovis antara lain untuk citra satelit/sensor: foto udara wilayah } \\
\text { Amerika Serikat, ASTER, EO-1 ALI dan Hyperion, seri satelit } \\
\text { Landsat (MSS, TM, ETM, dan OLI), dan MODIS } \\
\text { url: http://glovis.usgs.gov/ }\end{array}$ \\
\hline USGS Data Pool & url: https://lpdaac.usgs.gov/data access/data pool \\
\hline NASA Reverb & $\begin{array}{l}\text { Reverb adalah situs generasi terbaru yang disediakan oleh } \\
\text { NASA untuk mengunduh data yang dimiliki oleh Earth } \\
\text { Observation System (EOS) NASA. Beragam citra satelit dan } \\
\text { sensor, serta produk kebumian dapat diunduh. } \\
\text { url: http://reverb.echo.nasa.gov/reverb/ }\end{array}$ \\
\hline NASA & $\begin{array}{l}\text { Untuk mengunduh citra satelit AVIRIS, yakni } \\
\text { http://aviris.jpl.nasa.gov/alt locator/ }\end{array}$ \\
\hline $\begin{array}{l}\text { European Space } \\
\text { Agency }\end{array}$ & $\begin{array}{l}\text { Beberapa satelit yang dikelola oleh European Space Agency } \\
\text { (ESA) dapat diunduh secara gratis setelah melakukan registrasi. } \\
\text { url 1: https://earth.esa.int/web/guest/data-access/online- } \\
\underline{\operatorname{archives}} \\
\text { url 2: } \underline{\text { http://www.vito-eodata.be/PDF/portal/Application. }} \\
\underline{\text { html\#Home }}\end{array}$ \\
\hline $\begin{array}{l}\text { National Institute for } \\
\text { Space Research/ } \\
\text { Brazil Space Agency }\end{array}$ & $\begin{array}{l}\text { China-Brazil Earth Resources Satellite program (CBERS) } \\
\text { adalah salah satu satelit yang tidak banyak diketahui oleh } \\
\text { khalayak. Satelit ini merupakan hasil kerjasama antara agensi } \\
\text { antariksa Brazil dan Cina, yang memiliki resolusi spasial } \\
\text { bervariasi dari } 2,7 \mathrm{~m} \text { (pankromatik) hingga } 20 \mathrm{~m} \text { (multispektral). } \\
\text { url: http://www.dgi.inpe.br/CDSR/ }\end{array}$ \\
\hline
\end{tabular}

Sumber : (Fawzi \& Jatmiko, 2018)

Hal apa saja yang dipertimbangkan dalam penggunaan data Penginderaan Jauh

Interpretasi data penginderaan jauh harus melalui banyak pertimbangan dalam upaya untuk menghasilkan data yang akurat, mengingat ketidakpastian yang melekat pada datanya (Rocchini et al., 2013). Pertimbangan utama dalam pemilihan data penginderaan jauh adalah tujuan pemetaan. Tujuan pemetaan menentukan skala peta yang dihasilkan. Jika skala yang dihasilkan adalah skala besar, maka memerlukan citra penginderaan jauh dengan resolusi spasial yang tinggi, dan sebaliknya jika tujuan dibutuhkan peta skala kecil. Hal 
berpengaruh lainnya adalah luas area kajian karena resolusi spasial menengah hingga kecil memiliki cakupan area yang lebih besar pula. Akan tetapi, kawasan pesisir pada umumnya memiliki aktivitas beragam yang membutuhkan pemetaan menggunakan citra penginderaan jauh resolusi yang tinggi, yang tentunya tergantung jumlah biaya yang tersedia yang akan berpengaruh pada spesifikasi pemetaan dan penggunaan citra penginderaan jauh yang lebih sesuai, bisa jadi berbeda sensor namun memiliki resolusi spasial yang sama atau tidak jauh berbeda.

\section{Produk Pesisir yang Dihasilkan dari Penginderaan Jauh}

Mengatasi isu-isu yang telah disebutkan di atas, dan pemenuhan perolehan informasi untuk kawasan pesisir, telah banyak produk pemetaan yang dihasilkan dengan menggunakan citra penginderaan jauh. Produkproduk pemetaan tersebut dapat berupa pemetaan sumberdaya pesisir, pulaupulau kecil, monitoring perubahan lingkungan, bencana seperti tumbahan oli dan tsunami, pengukuran faktorfaktor biofisik seperti: warna laut, suhu permukaan laut, kandungan klorofil, material tersuspensi, dan tata guna lahan (Fawzi, 2016). Secara lebih rinci terhadap produk dan data penginderaan jauh yang digunakan, disajikan pada Tabel 2.

Tabel 2. Produk informasi tentang pesisir yang diperoleh dari data penginderaan jauh.

\begin{tabular}{|l|l|}
\hline \multicolumn{1}{|c|}{ Aplikasi } & \multicolumn{1}{|c|}{ Data penginderaan jauh } \\
\hline $\begin{array}{l}\text { Pemetaan banjir } \\
\text { di kawasan } \\
\text { pesisir }\end{array}$ & $\begin{array}{l}\text { Data yang dibutuhkan untuk pemetaan banjir meliputi data } \\
\text { ketinggian. Data ketinggian dapat diperoleh melalui survei terestris } \\
\text { ataupun dengan penginderaan jauh seperti data Digital Elevation } \\
\text { Model (DEM) dan Light Detection and Ranging (LIDAR). }\end{array}$ \\
\hline $\begin{array}{l}\text { Pemetaan habitat } \\
\text { perairan dangkal yang dimaksudkan adalah ekosistem alami yang berada } \\
\text { di kawasan pesisir. Pemetaan habitat dilakukan untuk melakukan } \\
\text { monitoring perubahan ataupun kerusakan ekosistem yang biasanya } \\
\text { meliputi terumbu karang, padang lamun dan mangrove. Data } \\
\text { penginderaan jauh yang mempunyai panjang gelombang tampak } \\
\text { hampir semuanya dapat digunakan untuk aplikasi ini. }\end{array}$ \\
\hline $\begin{array}{l}\text { Parameter-parameter kualitas air tidak semuanya dapat dianalisis } \\
\text { menggunakan data penginderaan jauh. Parameter fisik seperti suhu } \\
\text { permukaan laut (SPL) dapat diekstraksi dengan citra penginderaan } \\
\text { jauh termal. Kualitas air juga dapat diperoleh melalui pengembangan } \\
\text { kualitas air }\end{array}$ \\
$\begin{array}{l}\text { algoritma pemrosesan citra untuk deteksi kandungan klorofil, } \\
\text { sedimentasi, tumpahan minyak, hingga pencemaran dari industri. } \\
\text { Saat ini NASA telah meluncurkan beberapa satelit yang memang } \\
\text { dikhususkan untuk memonitoring kualitas perairan seperti } \\
\text { OrbView-2/SeaWiFS. }\end{array}$ \\
\hline
\end{tabular}




\begin{tabular}{|c|c|}
\hline $\begin{array}{l}\text { Pemetaan dan } \\
\text { monitoring garis } \\
\text { pantai }\end{array}$ & $\begin{array}{l}\text { Pemetaan garis pantai biasanya menggunakan data multitemporal. } \\
\text { Penggunaan data multitemporal dimaksudkan untuk mengetahui } \\
\text { seberapa besar perubahan garis pantai baik yang berupa akresi } \\
\text { ataupun abrasi. Penggunaan citra penginderaan jauh dibatasi } \\
\text { pada citra dengan resolusi menengah hingga tinggi dengan } \\
\text { dikombinasikan oleh data terestris yang beresolusi lebih tinggi. }\end{array}$ \\
\hline $\begin{array}{l}\text { Perubahan } \\
\text { penggunaan } \\
\text { lahan dan } \\
\text { perencanaan } \\
\text { regional }\end{array}$ & $\begin{array}{l}\text { Sebagian besar dari citra penginderaan jauh dapat digunakan untuk } \\
\text { aplikasi ini. Akan tetapi penggunaan citra penginderaan jauh resolusi } \\
\text { tinggi seperti Quickbird, IKONOS, SPOT-5 dan satelit lain sejenis } \\
\text { termasuk penggunaan pesawat tanpa awak/drone lebih disarankan } \\
\text { daripada citra resolusi rendah. Analisis perubahan penggunaan } \\
\text { lahan secara tidak langsung dapat digunakan untuk mendukung } \\
\text { perencanaan regional yang berada di kawasan pesisir seperti zonasi } \\
\text { tata ruang kawasan pesisir. }\end{array}$ \\
\hline Kebencanaan & $\begin{array}{l}\text { Isu bencana menjadi hal utama yang diperhatikan di Kawasan } \\
\text { pesisir. Bencana-bencana tersebut antara lain intrusi air laut, } \\
\text { penurunan muka tanah, tsunami, gempa bumi, dan erosi. Data } \\
\text { multitemporal mendukung inventori pra dan pasca bencana terjadi. } \\
\text { Upaya mendukung mitigasi dan rencana kontijensi dapat dilakukan } \\
\text { dengan data yang tersedia. }\end{array}$ \\
\hline
\end{tabular}

\section{Keterbatasan dan Perkembangan Keilmuan Lebih Lanjut}

Masih terdapat banyak keterbatasan dalam penggunaan data penginderaan jauh untuk kajian pesisir, terutama permasalahan sensor yang masih dikembangkan secara spesifik untuk mengkaji wilayah pesisir. Selain itu, metode pemetaan juga terus akan dikembangkan untuk meningkatkan akurasi pemetaan. Kurangnya integrasi pemetaan ke dalam perencanaan di kawasan pesisir, SDM yang kurang mengerti tentang pengolahan data spasial dan penginderaan jauh, dan kebutuhan data resolusi tinggi adalah menjadi permasalahan yang patut diselesaikan untuk pengelolaan kawasan pesisir yang lebih baik.

\section{PENUTUP}

Kebutuhan informasi untuk pengelolaan kawasan pesisir dalam upaya untuk menindaklanjuti isu-isu atau permasalahan yang berkembang adalah mutlak dibutuhkan dengan tepat, akurat dan cepat. Penginderaan jauh telah menyediakan kapabilitas untuk menyediakan informasi tersebut melalui penerjemahan informasi nilai piksel menjadi informasi tematik. Terlepas dari permasalahan metode pemetaan yang ada, penggunaan penginderaan jauh kedepannya akan menjadi data utama terutama dalam monitoring dan pengukuran paremeter biofisik di kawasan pesisir. 


\section{DAFTAR PUSTAKA}

Adger, W. N., T. P. Hughes, C. Folke, S. R. Carpenter, and J. Rockström. 2005. Social-ecological resilience to coastal disasters. Science 309: 1036-1039.

Beyer, J., H. C. Trannum, T. Bakke, P. V. Hodson, and T. K. Collier. 2016. Environmental effects of the deepwater horizon oil spill: A review. Marine Pollution Bulletin 110: 28-51.

Brown, G., and V. H. Hausner. 2017. An empirical analysis of cultural ecosystem values in coastal landscapes. Ocean and Coastal Management 142: 49-60.

Corcoran, E., C. Nellemann, E. Baker, R. Bos, D. Osborn, and H. Savelli. 2010. Sick water? the central role of wastewater management in sustainable development, A rapid response assessment. UNEP, UN-HABITAT, GRIDArendal. Norway.

De Araujo Barbosa, C. C., P. M. Atkinson, and J. A. Dearing. 2015. Remote sensing of ecosystem services: A systematic review. Ecological Indicators 52: 430443.

De Sherbinin, A., A. Schiller and A. Pulsipher. 2007. The vulnerability of global cities to climate hazards. Environment and Urbanization 19: 39-64.

Doocy, S., Y. Gorokhovich, G. Burnham, D. Balk, and C. Robinson. 2007.
Tsunami mortality estimates and vulnerability mapping in Aceh, Indonesia. American journal of public health 97: S146-S151.

Emanuel, K., 2005. Increasing destructiveness of tropical cyclones over the past 30 years. Nature 436: 686-688.

Fawzi, N. I., 2016a. Penginderaan jauh untuk lingkungan dan konservasi. Penerbit Ombak, Yogyakarta. 296 hal.

Fawzi, N. I., 2016b. Mangrove: karakteristik, pemetaan, dan pengelolaannya. Penerbit Sibuku, Yogyakarta. 114 hal.

Fawzi, N. I., 2017. Analysis change and management strategy of mangrove Forest in Gunung Palung National Park, North Kayong Regency, West Kalimantan. Coastal and Ocean Journal 1: 27-38.

Fawzi, N. I., dan R. H. Jatmiko. 2018. Penginderaan jauh sistem termal dan aplikasinya. Penerbit Ombak. Yogyakarta. 204 hal.

Gandy, M., 2004. Rethinking urban metabolism: water, space and the modern city. City 8: 371387.

Glavovic, B. C., 2013. Coastal innovation imperative. Sustainability (Switzerland) 5: 934-954.

Klemas, V., 2011. Remote sensing of wetlands: Case studies 
comparing practical techniques. Journal of Coastal Research 27: 418-427.

Kuenzer, C., H. Guo, M. Ottinger, J. Zhang and S. Dech. 2013. Spaceborne thermal infrared observation An overview of most frequently used sensors for applied research. In: Kuenzer, C. and S. Dech, (Eds.), Thermal infrared remote sensing: sensors, methods, applications. Springer Netherlands, Dordrecht, hal. 131-148.

Lasut, H. E., N. J. Kawung and M. T. Lasut 2016. The Concentration of arsenic [As], in forms of suspended and dissolved arsenic, in Manado Bay coastal waters. Jurnal Pesisir dan Laut Tropis 1: 30-38.

Lo, C. P., 1987. Applied Remote Sensing. Longman Sc \& Tech, California. 393 hal.

Lotze, H. K., H. S. Lenihan, B. J. Bourque, R. H. Bradbury, R. G. Cooke, M. C. Kay, S. M. Kidwell, M. X. Kirby, C. H. Peterson and J. B. C. Jackson. 2006. Depletion degradation, and recovery potential of estuaries and coastal seas. Science 312: 1806-1809.

Malone, T., M. Davidson, P. Digiacomo, E. Gonçalves, T. Knap, J. Muelbert, J. Parslow, N. Sweijd, T. Yanagai, and H. Yap. 2010. Climate change, sustainable development and coastal ocean information needs. Procedia Environmental Sciences 1: 324-341.

Melesse, A., Q. Weng, S. Prasad and G. Senay. 2007. Remote sensing sensors and applications in environmental resources mapping and modelling. Sensors 7: 3209-3241.

Monecke, K., W. Finger, D. Klarer,W. Kongko, B. G. McAdoo, A. L. Moore and S. U. Sudrajat. 2008. A 1.000-year sediment record of tsunami recurrence in northern Sumatra. Nature 455: 1232-1234.

National Geographic Indonesia, 2014. Benarkah kematian akibat tsunami itu takdir? [WWW Document]. Refleksi Sepuluh Tahun Tsunami. URL http:// nationalgeographic.grid.id/ $\mathrm{read} / 13295964 /$ benarkahkematian-akibat-tsunami-itutakdir?page $=$ all

Rocchini, D., G. M. Foody, H. Nagendra, C. Ricotta, M. Anand, K. S. He, V. Amici, B. Kleinschmit, M. Förster,S. Schmidtlein, H. Feilhauer, A. Ghisla, M. Metz and M. Neteler. 2013. Uncertainty in ecosystem mapping by remote sensing. Computers and Geosciences 50: $128-135$.

Sampono, N., A. Purbayanto, J. Haluan, A. Fauzi, B. and M. Wiryawan, M. 2012. Dampak reklamasi Teluk Jakarta terhadap kegiatan 
penangkapan ikan di Teluk Jakarta. Jurnal Perikanan dan Kelautan Desember Dampak Reklamasi Teluk Jakarta 2: 105-112.

Singkran, N., 2014. Contingency plan improvement for managing oil spills in the coastal waters of Thailand. Marine Pollution Bulletin 89: 149-159.

Sofian, I., A. Supangat, M. S. Fitriyanto, and R. Kurniawan. 2011. Memahami dan mengantisipasi dampak perubahan iklim pada pesisir dan laut di Indonesia Bagian Timur. Jurnal Meteorologi dan Geofisika 12: 53-64.

Sulistyono, S., S. Suntoro and M. Masykuri. 2012. Kajian dampak tumpahan minyak dari kegiatan operasi kilang minyak terhadap kualitas air dan tanah (Studi Kasus Kilang Minyak Pusdiklat Migas Cepu). Ekosains 4: 2334.

Teeling, H., B. M. Fuchs, D. Becher, C. Klockow, A. Gardebrecht, C. M. Bennke, M. Kassabgy, S. Huang, A. J. Mann, J. Waldmann, M. Weber, A. Klindworth, A. Otto, J. Lange, J. Bernhardt, C. Reinsch,M. Hecker, J. Peplies, F. D Bockelmann, U. Callies, G. Gerdts, A. Wichels, K. H. Wiltshire, F. O Glöckner,T. Schweder, and R. Amann. 2012. Substrate-controlled succession of marine bacterioplankton populations induced by a phytoplankton bloom. Science 336: 608-611.

Van Rijn, L. C., 2011. Coastal erosion and control. Ocean and Coastal Management 54: 867-887.

Vikas, M., and G. S. Dwarakish. 2015. Coastal pollution: A review. Aquatic Procedia 4: 381-388.

Werner, A. D. and C. T. Simmons. 2009. Impact of sea-level rise on sea water intrusion in coastal aquifers. Ground Water 47: 197-204.

Williams, S. J., 2013. Sea-level rise implications for coastal regions. Journal of Coastal Research Special Is: $184-196$.

Yuliana, Y., E. M. Adiwilaga, E. Harris and N. T Pratiwi. 2012. Hubungan antara kelimpahan fitoplankton dengan parameter fisik-kimiawi perairan Teluk Jakarta. Jurnal Akuatika 3: 169-179.

Zaggia, L., G. Lorenzetti, G. Manfé, G. M. Scarpa, E. Molinaroli,K. E. Parnell, J. P. Rapaglia, M. Gionta and T. Soomere. 2017. Fast shoreline erosion induced by ship wakes in a coastal lagoon: Field evidence and remote sensing analysis. PLoS ONE 12: 187-210.

Zhang, K., B. C. Douglas and S. P. Leatherman. 2004. Global warming and coastal erosion. Climatic Change 64: 41-58. 